Linköping University Medical Dissertation No. 1583

\title{
Inflammation and tendon healing
}

\author{
Parmis Blomgran
}

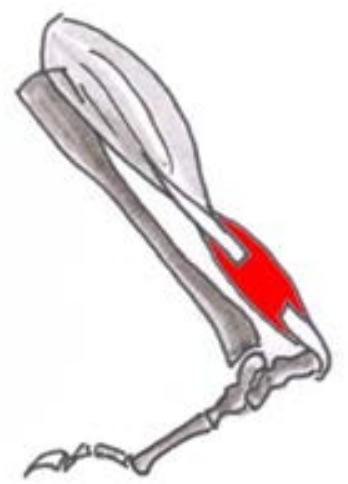

Division of Clinical Sciences

Department of Clinical and Experimental Medicine

Faculty of Medicine and Health Sciences

Linköping University

Linköping, Sweden 2017

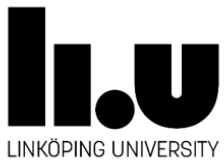


(C) Parmis Blomgran 2017

Articles have been reprinted with permission of the respective copyright owners.

Cover and title page illustration by Per Aspenberg

During the course of research underlying this thesis, Parmis Blomgran was enrolled in Forum Scientium, a multidisciplinary doctoral program at Linköping University, Sweden.

Printed by LiU-Tryck, Linköping, Sweden, 2017

ISBN: $978-91-7685-471-6$

ISSN: 0345-0082 
Only those who will risk going too far can possibly find out how far one can go

T.S. Eliot 


\section{Supervisor}

Per Aspenberg

Professor, Department of Clinical and Experimental Medicine, Linköping University

\section{Co-supervisor}

Jan Ernerudh

Professor, Department of Clinical and Experimental Medicine, Linköping University

\section{Faculty Opponent}

Patrik Danielson

Professor, Department of Integrative Medical Biology, Umeå University

\section{Committee board}

Michael Kjaer

Professor, Institute of Sports Medicine Copenhagen, Bispebjerg Hospital, University of Copenhagen, Denmark

Torbjörn Bengtsson

Professor, Department of Medical Sciences, Örebro University

Lennart Svensson

Professor, Department of Clinical and Experimental Medicine, Linköping University 
To my parents 



\section{List of papers}

I. Blomgran P, Blomgran R, Ernerudh J, Aspenberg P

A possible link between loading, inflammation and healing: Immune cell populations during tendon healing in the rat

Scientific Reports. 2016; 6:29824

II. Blomgran P, Blomgran R, Ernerudh J, Aspenberg P

COX-2 inhibition and the composition of inflammatory cell populations during early and mid-time tendon healing

Muscle, Ligament and Tendons Journal. 2017; 7(2):223-229

III. Blomgran P, Hammerman M, Aspenberg P

Systemic corticosteroids improve tendon healing when given after the early inflammatory phase

Scientific Reports. 2017; 7(1):12468

IV. Hammerman $\mathrm{M}^{*}$, Blomgran $\mathbf{P}^{*}$, Ramstedt $\mathrm{S}$, Aspenberg $\mathrm{P}$ COX-2 inhibition impairs mechanical stimulation of early tendon healing in rats by reducing the response to microdamage Journal of Applied Physiology. 2015; 119(5):534-40

*Equal contribution 


\section{Abbreviations}

$\begin{array}{ll}\text { AP-1 } & \text { Activator protein } 1 \\ \text { COX } & \text { Cyclooxygenase } \\ \text { EP2 } & \text { Prostaglandin E2 receptor } 2 \\ \text { EP4 } & \text { Prostaglandin E2 receptor } 4 \\ \text { IL } & \text { Interleukin } \\ \text { INF- } \gamma & \text { Interferon gamma } \\ \text { iNOS } & \text { Inducible nitric oxide synthase } \\ \text { LPS } & \text { Lipopolysaccharide } \\ \text { NSAID } & \text { Nonsteroidal anti-inflammatory drug } \\ \text { PGE2 } & \text { Prostaglandin E2 } \\ \text { TGF- } \beta & \text { Transforming growth factor beta } \\ \text { Th cell } & \text { T helper cell } \\ \text { TNF } & \text { Tumor necrosis factor } \\ \text { Treg } & \text { Regulatory T cell }\end{array}$




\section{Table of contents}

Populärvetenskaplig sammanfattning...................................................... 1

Abstract........................................................................................................... 3

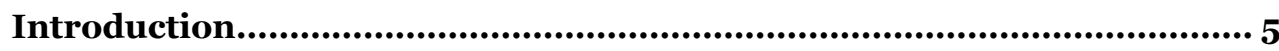

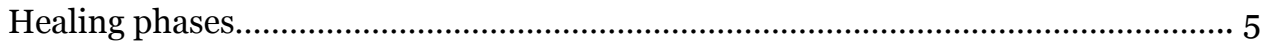

Factors that influence tendon healing.................................................................. 7

Mechanical loading............................................................................................. 7

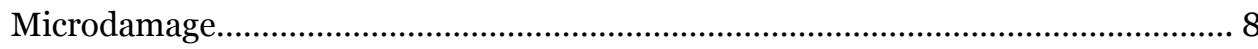

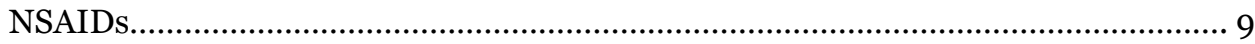

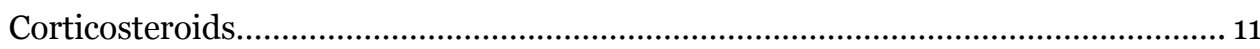

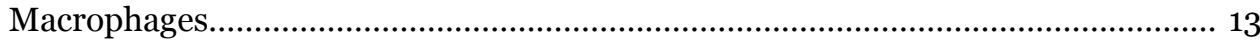

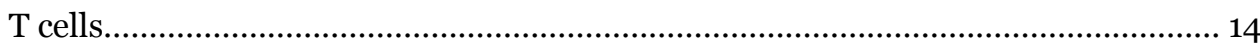

Aims....................................................................................................... 15

Comments on materials and methods......................................................... 17

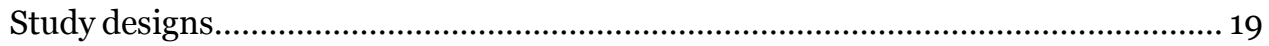

Results and discussion.............................................................................. 25

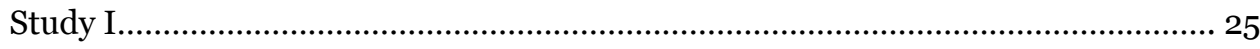

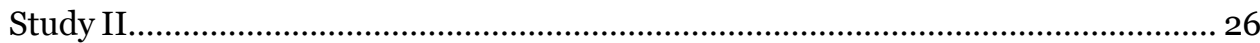

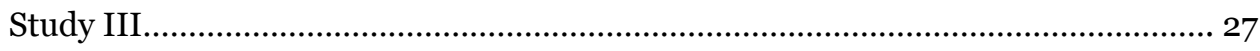

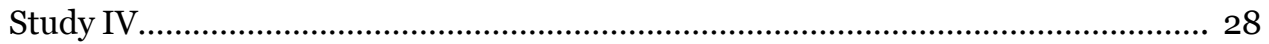

General discussion.................................................................................. 31

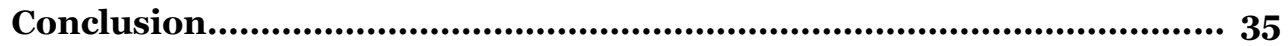

Acknowledgements................................................................................... 37

References................................................................................................ 39 



\section{Populärvetenskaplig sammanfattning}

Läkning efter skador börjar med inflammation: Vita blodkroppar kommer till området och antas sätta igång och styra processen. Detta torde även gälla skadade senor och ledband, men det är aldrig klargjort vilka sorters blodkroppar som är inblandade i senläkning och hur sammansättningen av olika sorter ändras med tiden. Vi har studerat detta i en råttmodell, där vi skär av hälsenan och låter den läka utan vidare åtgärder. I det första delarbetet beskriver vi hur en sorts "aggressiva" immunceller (makrofager) dominerar till en början, för att sedan ersättas av "konstruktiva" immunceller. De förra anses förhindra eller avbryta infektioner, medan de senare stimulerar ickeinflammatoriska celler att börja göra ny senvävnad. Vi fann också att mekanisk belastning fördröjde detta skifte. Den förlängda initiala, aggressiva inflammationen torde vara orsaken till att belastade senor blir tjockare under läkningen.

Det är känt att anti-inflammatoriska läkemedel (NSAID) försämrar senläkningen om de ges under den tidiga fasen. Vi tänkte att detta kunde ske genom att antalet och sammansättningen av de vita blodkropparna i senan påverkades, men kunde i delarbete två inte visa att så var fallet. Sannolikt påverkar NSAID främst de senbildande cellerna direkt. Möjligen påverkas blodkropparnas utsöndring av signalmolekyler utan att deras antal ändras.

Kortison har däremot säkra effekter på inflammationen, som dämpas. Därför prövade vi kortison i samma modell i delarbete tre. Som väntat försämrade kortison senläkningen i mycket hög grad, om det gavs direkt efter operationen. Vi tänkte oss emellertid att inflammationen i ett senare läkningsskede skulle kunna störa uppbyggnaden av en mogen, välorganiserad senvävnad. I så fall skulle kortison, givet i ett senare skede, ha en gynnsam effekt. Så var också fallet: Mått på senvävnadens mekaniska kvalitet fördubblades och skillnaden var uppenbar för blotta ögat. 
NSAID försämrar senläkning. Sker detta genom att minska svaret på mekanisk belastning? Råttor belastar vanligtvis sin läkande hälsena hårt. Belastningen kan minskas bl a genom att förlama vadmusklerna med Botox-injektioner. I en serie försök i fjärde delarbetet såg vi detta: Ju större belastning, dess tydligare orsakade NSAID en hämning av stimulansen. Det är känt att råttornas spontana belastning kan leda till mikroskador i vävnaden. Detta simulerade vi genom upprepade nålstick i vävnaden, samtidigt som musklerna var förlamade. Nålsticken stimulerade läkningen och kunde delvis ersätta mekanisk belastning, men denna effekt blockerades fullständigt av NSAID.

Sammantaget belyser dessa studier hur inflammation, mekanisk belastning och mikroskador samspelar under senläkningen, och att läkningen i hög grad kan påverkas av läkemedel och belastning. 


\section{ABSTRACT}

Tendons heal through three different overlapping phases; the inflammatory, proliferative and remodeling phase. Many studies have investigated what factors influence healing of tendons. However, little was known about inflammation and the immune cells present during Achilles tendon healing by the time this thesis started.

We developed a flow cytometry method for our rat model of tendon healing, which enabled us to study different leukocyte subpopulations during Achilles tendon healing.

The general aim of this thesis was to understand more about inflammation and the immune cell populations present during tendon healing and how the immune cell composition changes during normal tendon healing. Moreover, we investigated how different factors that are known to influence tendon healing affected the composition of the immune cell population.

First, we described the immune cells during the time course of tendon healing focusing on different subpopulations of macrophages and $\mathrm{T}$ cells. Then, we studied how these cells were influenced by reduced mechanical loading. Mechanical loading prolonged the presence of M1 macrophages and delayed the switch to regulatory $\mathrm{T}$ cells and M2 macrophages compared to reduced mechanical loading. Next, the effect of nonsteroidal anti-inflammatory drugs (NSAIDs) on the leukocyte composition revealed that, even though NSAIDs influence the mechanical properties of healing tendon, this effect was not mediated via changes in the leukocyte sub-populations during early and midtime tendon healing. Further, the effect of corticosteroids during the inflammatory and remodeling phases of tendon healing was an improved healing of tendons and a reduction of $\mathrm{CD} 8 \mathrm{a} \mathrm{T}$ cells when corticosteroid was administered after the inflammatory phase. Lastly, we investigated if impairment of tendon healing by NSAIDs was related to mechanotransduction 
or microdamage during mechanical loading and showed that NSAIDs impair tendon healing by reducing the response to microdamage.

In conclusion, these studies show that inflammation plays an important role during Achilles tendon healing, and factors that influence healing can also alter the presence or polarization of immune cell populations. 


\section{INTRODUCTION}

The Achilles tendon is the largest tendon in the body and can withstand forces up to 12 times the body weight ${ }^{1}$. Achilles tendon connects the gastrocnemius and soleus muscles to the calcaneal bone and is responsible to transmit force from muscle to bone. Ruptured tendons heal slowly, and management of tendon injuries is challenging. Mechanical loading improves healing of tendons and has been shown to modulate inflammation-related genes, which points to the important role of inflammation during tendon healing ${ }^{2-4}$. There are other factors affecting tendon healing, like nonsteroidal anti-inflammatory drugs (NSAIDs) and corticosteroids. However, the effect of these factors on inflammation-related tendon healing is not fully clarified. The purpose of this thesis was therefore, to describe inflammation and the immune cells involved during Achilles tendon healing, and to further investigate if mechanical loading and anti-inflammatory drugs influence healing via inflammation. Moreover, by effects on inflammation, we in this case mean measurable changes in either the frequency of immune cells in the healing tendon, their polarization or their activation.

\section{Healing phases}

Healing of ruptured tendons involves three phases. The process starts with an inflammatory phase, where the inflammatory cells are recruited to the site of injury. Neutrophils are the first cells to arrive at the site of injury to perform phagocytosis and debridement of the tissue. This is followed by macrophage recruitment. Macrophages have an antimicrobial role and are also involved in debridement of the wound through phagocytosis or efferocytosis, acting as one of the major scavenger cells 5 . Macrophages produce different growth factors and cytokines that not only result in recruitment of other cells like lymphocytes, but also control the proliferation of fibroblasts and synthesis of collagen that builds up the extracellular matrix ${ }^{6}$. The dual role that macrophages play in the debridement process and orchestration of new tissue formation makes them 
one of the most pivotal cells involved in the healing process. Tlymphocytes have an important role during wound healing as well, since depletion of $\mathrm{T}$ cells and their subtypes influence the mechanical strength and collagen content of the wound 7-9. The second phase of healing is the proliferative and matrix production phase where fibroblasts proliferate and produce mainly a disorganized matrix made of collagen type III. The final phase of healing is the remodeling of the injured tissue into a more organized extracellular matrix. Collagen type I is primarily produced during this phase and arranged in parallel to the direction of the force $5 ; 10$. How destructive inflammation shifts to a constructive inflammation is not fully understood. By the time this thesis started there was no clear picture of the role of inflammation and immune cells during the different phases of tendon healing. 


\section{Factors that influence tendon healing}

There are different factors that influence tendon healing, either by improving this process such as mechanical loading and microdamage, or by slowing down the early tendon healing process like NSAIDs and corticosteroids.

\section{Mechanical loading}

Many studies have evaluated the stimulatory effects of mechanical loading on healing tendons 2; 11-14. The mechanical properties of Achilles tendons can be influenced by different loading conditions during the different phases of healing. Mechanical loading improves the mechanical properties of healing tendons. Only 5 minutes of daily mechanical loading is enough to improve the healing of Achilles tendon in rats ${ }^{15}$.

In a complete unloading model, which combines muscle paralysis using Botox injection and tail suspension, the tendon callus shows poor mechanical properties. When loading is increased to moderate unloading, either Botox injection or tail suspension, the material properties of the tissue improves without an increase in structural properties such as cross-sectional area. Finally, when the loading further increases from moderate unloading to full loading (free cage activity), the material properties improve further and the cross-sectional area also increases. This implies that slight levels of mechanical loading improves the material property of the healing tendon tissue, while full loading makes the tendon regenerate bigger and thicker ${ }^{11}$. The fact that moderate unloading increases the tissue quality and full loading increases the mass of the healing tissue suggests that different stimulatory mechanisms could be involved in tendon healing in response to different degree of mechanical loading.

It is recommended for patients with tendon injuries to be immobilized during the inflammatory phase of healing. However, studies in our rat model have shown that short episodes of loading during either the inflammatory phase or the later phases both improve the healing process ${ }^{12}$. Although the outcome of loading at different phases of healing was the same, different mechanisms could 
be involved. In the same tendon healing model, it was shown that mechanical loading regulates inflammation-related genes during the inflammatory phase of tendon healing ${ }^{2-4}$. However, the possible influence of mechanical loading on magnitude and polarization of immune cells during the course of tendon healing needs to be further investigated.

\section{Microdamage}

Healing tissue that forms after tendon transection is fragile. Mechanical loading during the early phase of tendon healing increases the strength of the tendon in rats ${ }^{12 ; 14}$. Early mechanical loading seems to cause microdamage in the healing tendon in the form of micro-bleedings ${ }^{12}$. Inducing microdamage by needling (insulin needle penetration) in unloaded healing Achilles tendons improves the tendon healing tissue. The gene expression response to microdamage induced by needling in healing tendons has been shown to be similar to the gene response seen after mechanical loading ${ }^{16}$. These findings suggest that the response to mechanical loading in Achilles tendon healing could partly be due to microdamage in the tissue ${ }^{16}$. We have recently shown that full loading increases blood leakage in healing tendons compared to moderate unloading. The increased blood leakage is associated with an increase of inflammationrelated genes and an improvement of the structural properties (unpublished data; Hammerman, Blomgran et al). 


\section{NSAIDs}

NSAIDs block the cyclooxygenase (COX) enzymes and thereby inhibit the conversion of arachidonic acid to prostaglandins, thromboxanes and prostacyclin ${ }^{17 ; 18}$. There are two isoforms of cyclooxygenase; constitutive COX1 and inducible COX-2, which are stimulated by different cytokines and growth factors. Non-selective NSAIDs inhibit COX-1 and COX-2 and have gastrointestinal side effects. Selective NSAIDs target only COX-2 to reduce inflammation without the aforementioned side effects ${ }^{19}$.

NSAIDs have been shown to impair tendon healing in animal models ${ }^{20-23}$. NSAIDs treatment during the first few days after tendon trauma has a significant negative effect on the healing tissue ${ }^{20-23}$. However, if the treatment starts after the inflammatory phase, it has a slight positive effect ${ }^{20}$. This suggests that NSAIDs, at a clinically relevant dose for humans, have different effect on the tendon in animals depending on the time of administration (Table 1). Whether the effects of NSAIDs on tendon healing are related to an influence on inflammation and immune cells needs to be clarified. COX-2 is upregulated during tendon healing and mechanical loading has been shown to increase prostaglandin E2 (PGE2) ${ }^{24-26}$. COX inhibitors inhibit the production of PGE2, which is an important regulator of the mechanical adaptation in the tissue. It is known that COX inhibitors hinder the healing during the inflammatory phase. But whether this is mediated through abrogating the stimulatory effects of mechanical loading is not clarified. 


\begin{tabular}{|c|c|c|c|}
\hline Author & Drug & Duration treatment & Result \\
\hline Dimmen (2009) 22 & $\begin{array}{l}\text { parecoxib \& } \\
\text { indomethacin }\end{array}$ & twice daily for 7 days & $\begin{array}{l}\text { Day } 14 \downarrow \text { tensile strength } \\
\downarrow \text { cross sectional area }\end{array}$ \\
\hline Forslund (2003) ${ }^{27}$ & $\begin{array}{l}\text { celecoxib \& } \\
\text { indomethacin }\end{array}$ & daily for 14 days & $\begin{array}{l}\text { Day } 14 \downarrow \text { cross sectional area } \\
\text { †stress }\end{array}$ \\
\hline Thomas (1991) 28 & indomethacin & daily for 2 or 6 weeks & Week 2 - Week 6 - \\
\hline Virchecnko (2004) ${ }^{20}$ & parecoxib & $\begin{array}{l}\text { daily for first } 5 \text { days or } \\
\text { day 6-14 }\end{array}$ & $\begin{array}{l}\text { Day } 8 \text { for early treatment } \\
\downarrow \text { force at failure } \\
\text { Day14 for late treatment } \\
\downarrow \text { cross sectional area } \uparrow \text { stress }\end{array}$ \\
\hline
\end{tabular}

Table 1. Animal studies investigating the effect of NSAIDs on Achilles tendon healing. $\uparrow$ means increase, $\downarrow$ means decrease and - means no effect 


\section{Corticosteroids}

Corticosteroids were first used to treat rheumatoid arthritis in $1948{ }^{29 ;} 30$ and are today widely used for treatment of musculoskeletal disorders. Corticosteroids are one of the most routinely administered treatments for chronic tendon lesions ${ }^{31}$.

Inflammatory cascades initiate in response to tissue damage or pathogen recognition. Glucocorticoids, a class of corticosteroids, downregulate the proinflammatory transcription factors NF- $\kappa \mathrm{B}$ and AP-1, which leads to decreased expression of pro-inflammatory genes ${ }^{2}$. They also interfere with phospholipase A2 that acts on membrane phospholipids to release arachidonic acid 33. Glucocorticoids limit prostaglandin and nitric oxide synthesis and inhibit vasodilation and increase in vascular permeability, thereby reducing the blood flow and reducing leukocytes recruitment to the inflamed site 34 . Glucocorticoids inhibit pro-inflammatory cytokines expression such as that of IL-6, TNF, IL-1 $\beta$, IFN- $\gamma{ }^{32}$. Glucocorticoids play a key role in resolving the inflammation by influencing gene programs in monocytes and macrophages to start phagocytosing cellular debris and apoptotic cells $35 ; 36$. This gene programming in macrophages results in activation of alternatively activated macrophages (M2) and thereby secretion of anti-inflammatory cytokines such as TGF- $\beta$ and IL-10 37. Glucocorticoids downregulate genes involved in lymphocyte recruitment as well as their activation ${ }^{32}$.

Most studies show deleterious effects by local injection of corticosteroid on intact and healing tendons $38-45$. This is due to their anti-inflammatory effects and suppression of collagen synthesis, fibroblast proliferation, and extracellular matrix formation as well as showing reduced proliferation, viability, and migration of tenocytes $46-49$. Few studies report a positive effect of local corticosteroid treatment on intact tendons 50-53, whereas others showed no effect of corticosteroids on mechanical properties $54-57$.

Initiation of inflammation and its resolution are important for optimal healing. A study investigating the effects of NSAID treatment during the early inflammatory phase and later phase clearly showed that inflammation has 
different roles during the different phases of healing and therefore its downregulation has different outcomes ${ }^{20}$. As corticosteroids, like NSAIDs, are described to be anti-inflammatory, they might act differently during different phases of Achilles tendon healing. 


\section{Macrophages}

Macrophages are vital components of the innate immune system which recognize invading microorganisms, engulf and present them in form of antigens to $\mathrm{T}$ cells and further activate the adaptive immune system. Furthermore, macrophages are key regulators during development and homeostasis by phagocytosing apoptotic cells and cell debris and further partake in the remodeling of the tissue. Macrophages are heterogeneous cell population and react to physiological and microenvironmental changes by adapting different phenotypes. Classical activation of macrophages (M1) is induced by LPS and INF- $\gamma$ and is associated to a Th1 response. M1 macrophages produce pro-inflammatory cytokines such as TNF, IL-6, IL-12 and IL-1 $\beta$. Alternative activation of macrophages (M2) is associated to stimulation with IL4 and IL-13 and is linked to a Th2 response. M2 macrophages produce antiinflammatory cytokines such as IL-10 and TGF- $\beta$ 58. Functional characterization of macrophages can be described by the expression of iNOS in M1 macrophages, which is an enzyme converting arginine to nitric oxide to provide a cytotoxic environment to destroy pathogens. Moreover, by expression of arginase in M2 macrophages, which converts arginine to ornithine, proline and polyamines, which promote cell proliferation and differentiation and collagen production by fibroblasts 59 . At least three M2 macrophage subtypes are described (M2a, M2b and M2c) ${ }^{60}$. CD206 expressing macrophages are of M2a subtype and the result of polarization by IL-4 and IL-13, and can drive Th2 responses. CD163 expressing macrophages are of M2c subtype, can be polarized by IL-10 and glucocorticoids, and promote the development of Th2 lymphocytes as well as expansion of Tregs ${ }^{61}$. 


\section{T cells}

$\mathrm{T}$ cells have an important role in the adaptive immune response. CD4 helper (Th) $\mathrm{T}$ cells coordinate immune responses against pathogens. Naïve Th cells leave the thymus and recirculate between the blood and secondary lymphoid organs. Naiive Th cells will be activated in the secondary lymphoid organs when encountering antigens presented by antigen-presenting cells, and based on a particular cytokine environment differentiate into a distinct Th cell subset such as Th1, Th2, Th17 and inducible regulatory T (iTreg) cells (Figure 1). Activated CD4 helper $\mathrm{T}$ cells recruit phagocytes like macrophages to eliminate microbes 62; 63. Regulatory T cells produce anti-inflammatory cytokines, such as TGF- $\beta$ and IL-10, which restrict effector immune responses ${ }^{64}$. CD8 cytotoxic T cells will be activated upon recognizing antigen of their target cell. They contain cytotoxic granules that release proteins including perforin and granzymes. Perforins form pores in the plasma membrane of the targeted cells and enable diffusion of granzyme into the cytosol of the target cell. Granzymes are proteases that when entering the cells cause apoptotic cell death ${ }^{6}$.

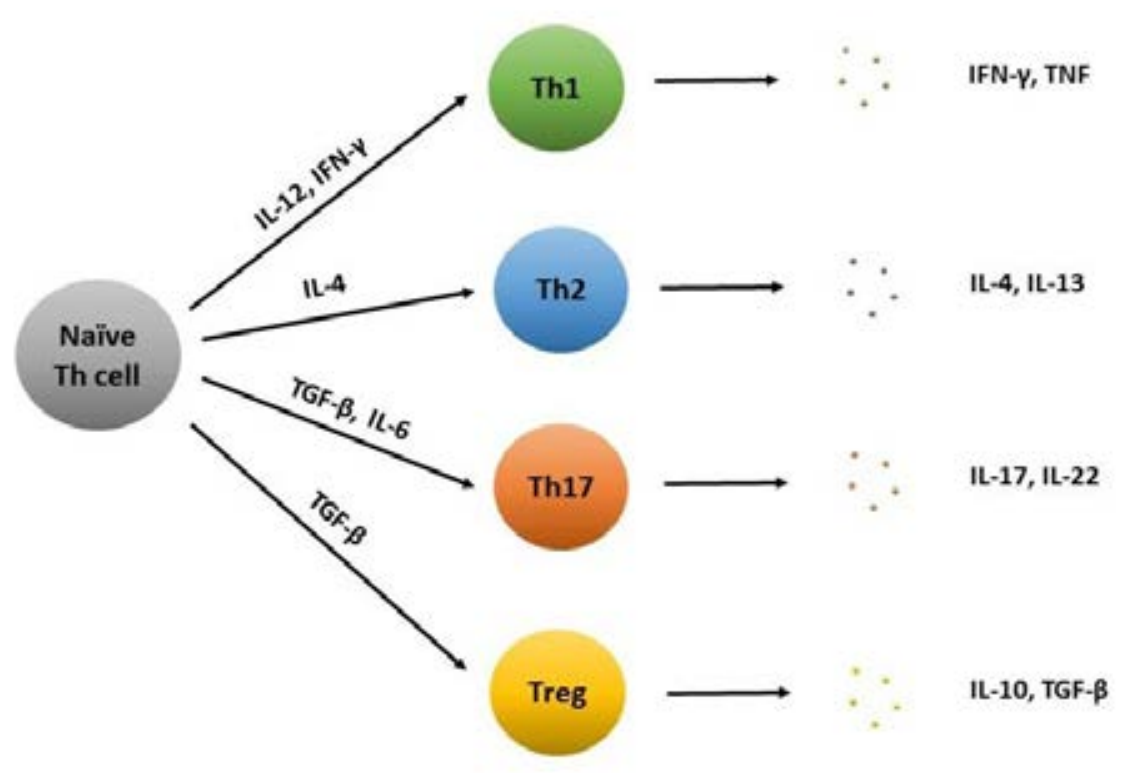

Figure 1. Schematic representation of $\mathrm{CD} 4 \mathrm{~T}$ helper cell differentiation. 


\section{AIMS}

\section{General}

The general aim of this thesis was to describe the composition of the immune cell populations present during tendon healing and how this composition changes with time. Furthermore, we aimed at understanding how different factors, which regulate healing, also affect the composition of the immune cell populations in the healing tissue.

\section{Specific}

Study I: To describe the status of inflammation and inflammatory cells involved at different time points during Achilles tendon healing and to investigate how these immune cell populations are influenced by different degrees of mechanical loading.

Study II: To study if NSAIDs (COX-2 inhibitors) influence the composition of leukocyte populations during early and mid-time tendon healing.

Study III: To study if the restriction of inflammation, using corticosteroids, during the early remodeling phase could improve tendon healing.

Study IV: To elucidate if the impairment of tendon healing by NSAIDs (COX2 inhibitors) during early tendon healing is related to mechanical loading. More precisely, if the impairment is due to interference with mechanotransduction or the microdamage created during loading. 


\section{COMMENTS ON MATERIALS AND METHODS}

Ethical and technical issues make human studies limited. Among animal models, the rat model is fast, cost-efficient and can provide a reproducible model to perform research. There are differences between rats and humans. Rats are quadrupeds and might load their tendons with a different magnitude. However, healing phases, cells involved and basic biological mechanisms should be quite similar and make it possible to study how different factors influences them.

We have used healthy Achilles tendon in rats that underwent sharp Achilles tendon transection to study tendon healing. This is different from ruptured Achilles tendon in humans with frayed ends that might have had degenerative changes prior to rupture. However, we used a tendon transection model since we need to have a standard method that is easily reproducible.

We have used botulinum toxin A (Botox) to moderately or partially unload the tendon. Botox injections into the calf muscles inhibit acetylcholine production and as a result, prevents signal transmission from nerve cells to the muscle and thereby causes paralysis of the muscle.

Rats are adapted to avoid predation, and therefore may avoid limping or slowing down in case of injury. Therefore, the loading of their healing Achilles tendon during free cage activity (full loading) is probably close to maximal. In contrast, patients normally do not apply maximal load on their injured tissues. Therefore, rats with reduced loading due to Botox paralysis probably better mimic the clinical condition in humans. Full loading represents a model for increased or exaggerated loading in humans.

All rats included in all 4 studies performed in this thesis were female SpragueDawley rats purchased from Taconic (Taconic, Ejby, Denmark). All experiments were performed in an animal facility where rats were exposed to a rather bacterially contaminated environment and were challenged by pathogens. 
Newer animal facilities are cleaner and allow pathogen-free animals. Laboratory animals with an unchallenged immune system seem to be irrelevant to humans 65 . 


\section{Study designs}

Study I: A possible link between loading, inflammation and healing: immune cell populations during tendon healing in the rat

This study was based on two experiments with 4 different time points (Figure 2). The right Achilles tendon was transected. Half of the rats received Botox injections into the right calf muscle to reduce mechanical loading (moderate unloading group) and the other half had free cage activity (full loading group). Animals were euthanized 1, 3, 5 and 10 days after surgery for flow cytometry evaluation of immune cells (Table 2).

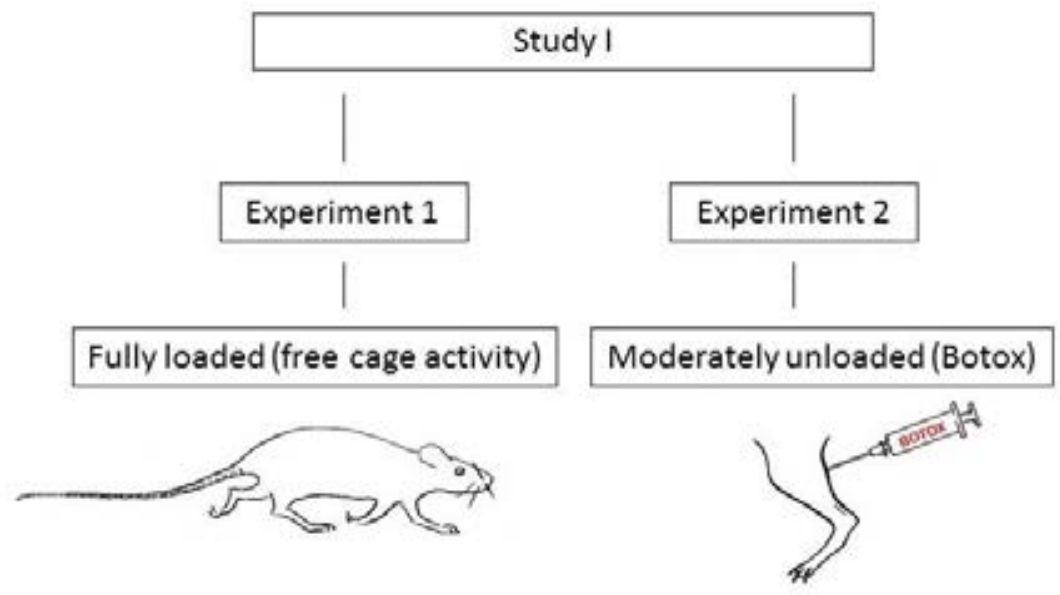

Figure 2. Experimental setup for study 1. We studied the effects of loading and moderate unloading on immune cell populations. 
Study II. COX-2 inhibition and the composition of inflammatory cell populations during early and mid-time tendon healing

In the first experiment, the right Achilles tendon was transected and rats received subcutaneous injections of parecoxib $(6.4 \mathrm{mg} / \mathrm{kg})$ or saline days $0-4$ and were euthanized on day 7 for mechanical evaluation of the healing tissue.

In the second and main experiment, the right Achilles tendon was transected and rats received parecoxib $(6.4 \mathrm{mg} / \mathrm{kg})$ or saline on days $0-2$ and were euthanized day 3 or received parecoxib or saline days 6-9 and were euthanized at day 10 for flow cytometry evaluation of immune cells (Figure 3).

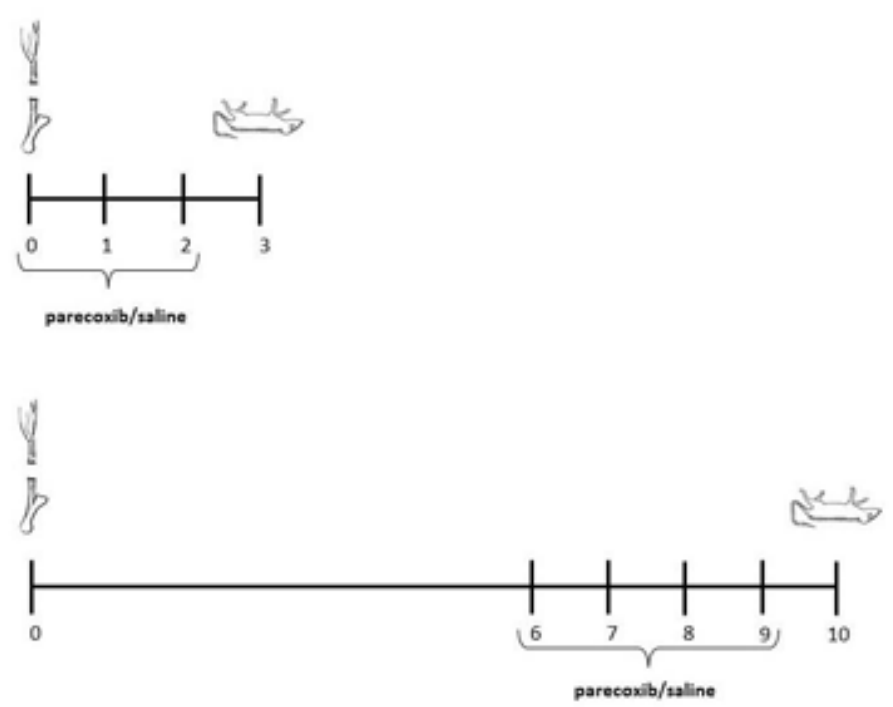

Figure 3. Experimental setup for flow cytometry evaluation in study 2. We studied the effects of parecoxib (COX-2 inhibitor) on immune cell populations during early and mid-time tendon healing. 
Study III. Systemic corticosteroids improve tendon healing when given after the early inflammatory phase

The right Achilles tendon was transected and rats received subcutaneous injections of dexamethasone $(0.5 \mathrm{mg} / \mathrm{kg})$ or saline on days $0-4$ and were euthanized on day 7 for mechanical testing and flow cytometry evaluation. The other group received dexamethasone or saline days 5-9 and were euthanized at day 12 for mechanical, histological evaluation and flow cytometry analysis (Figure 4).

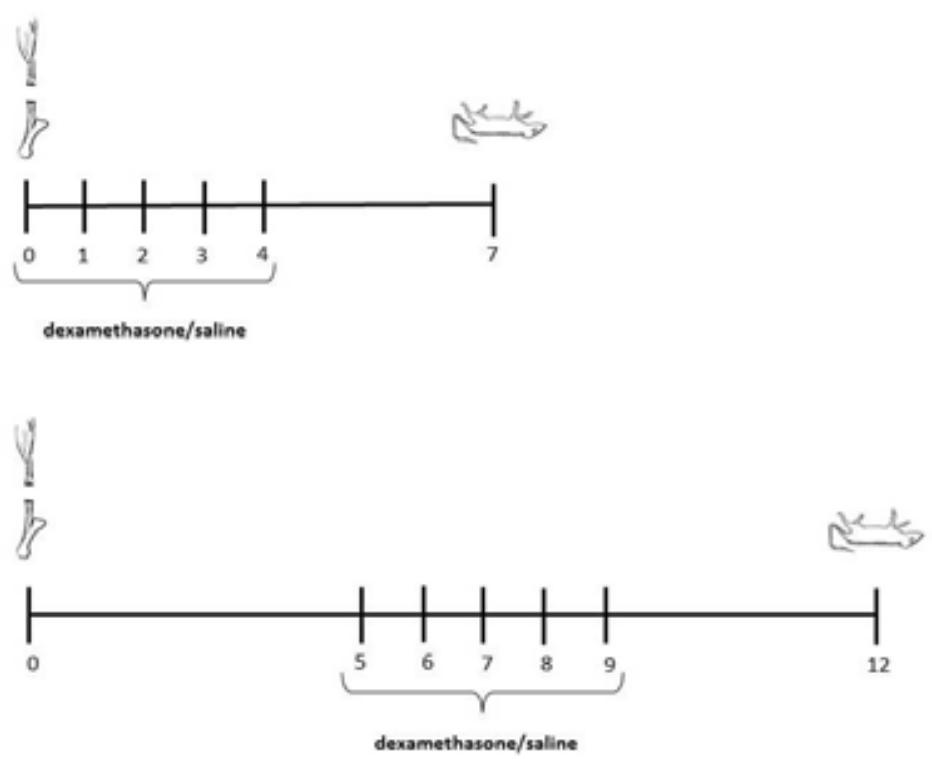

Figure 4. Experimental setup for study 3. We studied the effects of dexamethasone on healing tendon during the inflammatory and early remodeling phase. 
Study IV. COX-2 inhibition impairs mechanical stimulation of early tendon healing in rats by reducing the response to microdamage

This study was based on two experiments (Figure 5). The right Achilles tendon was transected. The first experiment consisted of 3 degrees of loading:

1. Full loading (free cage activity)

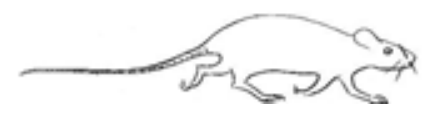

2. Moderate/partial unloading (Botox injection into the calf muscles)

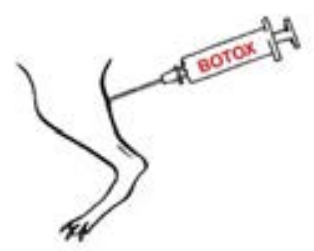

3. Unloading (combination of Botox and tail suspension)

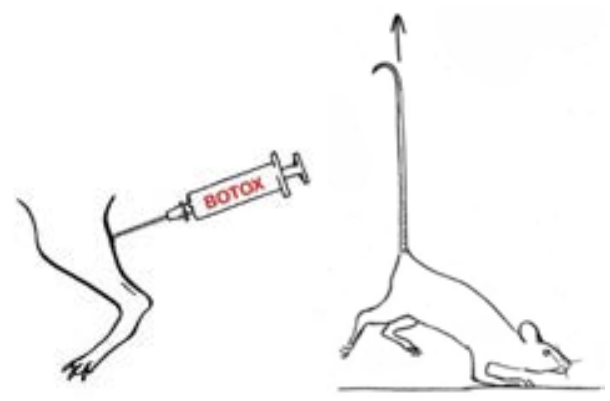

Rats in each group received subcutaneous injections of either parecoxib (6.4 $\mathrm{mg} / \mathrm{kg}$ ) or saline on days $0-4$ and were euthanized at day 7 for mechanical evaluation.

In the second experiment all rats were moderately unloaded with Botox and consisted of 3 groups:

1 and 2. Needling on days 2-5 with parecoxib or saline injections on days 0-5 

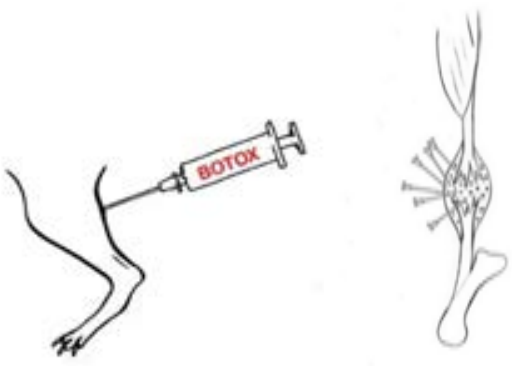

3. No needling and no injections

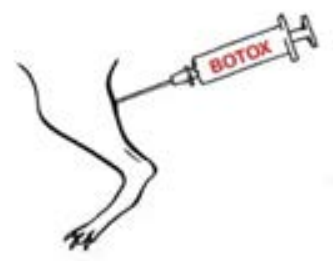

Rats were euthanized at day 8 and healing tissues were evaluated by mechanical testing.

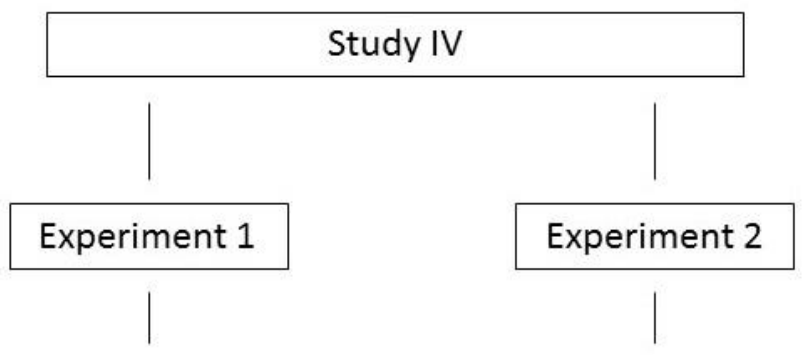

- Fully loaded with parecoxib/saline

- Moderately unloaded with parecoxib/saline

- Unloaded with parecoxib/saline

Moderately unloaded

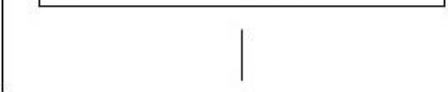

- Needling with parecoxib/saline - No needling

Figure 5. Experimental setup for study 4. We studied if the impairment of early tendon healing by parecoxib is related to inhibiting the response to mechanotransduction or microdamage. 
Table 2. Markers studied by flow cytometry

\begin{tabular}{|l|l|}
\hline Marker & Cell type \\
\hline CD45 & Leukocyte \\
\hline CD11b & Phagocyte \\
\hline CD68 & Pan-macrophage \\
\hline CCR7 & M1 macrophage \\
\hline CD163 & M2c macrophage \\
\hline CD206 & M2a macrophage \\
\hline CD3 & T cell \\
\hline CD4 & T helper \\
\hline CD25 & CD25 ${ }^{+}$Foxp3 ${ }^{+}$ \\
& Regulatory T cell \\
\hline Foxp3 & Regulatory T cell \\
\hline CD8a & Cytotoxic T cell \\
\hline
\end{tabular}

Table 3. Overview of methods used in the articles

\begin{tabular}{|l|llll|}
\hline Study & I & II & III & IV \\
\hline Tendon transection & X & X & X & X \\
Botox injection & X & & & X \\
Tail suspension & & & & X \\
Flow cytometry & X & X & X & \\
Mechanical testing & & X & X & X \\
Histology & & & X & X \\
\hline
\end{tabular}




\section{RESULTS AND DISCUSSION}

\section{Study I}

In this study, we described the immune cells signature during different phases of tendon healing and further investigated how inflammatory cells are influenced by the different degrees of mechanical loading.

With full cage activity (full loading), the regenerating tissue contained $83 \%$ leukocytes $\left(\mathrm{CD} 45^{+}\right)$on day 1 , which decreased over time and only $23 \%$ of all cells in the regenerated tissue on day 10 were leukocytes. The majority of these cells were the innate immune cells. Macrophages constituted $47 \%$ of all leukocytes at day 1 and $17 \%$ at day 10 . The M1 macrophage marker CCR7 showed an early abundance at day 3 which was further increased by day 10. The CD163 ${ }^{+}$ macrophages (M2c) were more or less constant over the time points investigated, although exhibiting a small increase from day 1 to day $3 . \mathrm{CD}^{206^{+}}$ macrophages (M2a) increased dramatically from day 5 to 10. A small percentage of leukocytes were adaptive immune cells. In contrast to macrophages that decreased over time, $\mathrm{T}$ cells and their subtypes, ( $\mathrm{T}$ helper and cytotoxic $\mathrm{T}$ cells) increased.

With reduced loading by Botox, markers related to down regulation of inflammation were more common day 5, particularly CD206 and activated and regulatory $\mathrm{T}$ cells. By day 10, these cells had disappeared in the Botox-treated animals but were still present with full loading. This means that with Botox treatment, inflammation was resolved between 5 and 10 days.

Full loading appeared to prolong the early type of inflammatory reaction, dominated by M1 macrophages, and delayed the switch to a "constructive" type of inflammation with more M2 macrophages and regulatory T cells. In this model, full mechanical loading leads to increased mechanical strength due to an increased mass of the healing tissue ${ }^{11}$. Since mechanical loading prolonged inflammation, and has been shown to make tendon callus bigger, it might be 
speculated that inflammation is responsible for the increase in the callus tissue mass.

\section{Study II}

In this study, we investigated if COX-2 inhibitors influence tendon healing via inflammation and thereby the composition of inflammatory cell populations.

Mechanical evaluation at day 7 showed that peak force, stiffness and crosssectional area were significantly decreased in the animals receiving the COX-2 inhibitor (parecoxib) during the first 4 days.

Further, flow cytometry data showed that parecoxib did not influence the M1/M2 macrophage ratio at day 3 or at day 10. None of the leukocyte cell populations studied were influenced by parecoxib treatment at any time point. The pattern of the leukocyte cell populations was similar between the parecoxib treated and saline (control) groups both at day 3 and at day 10. However, most of the cell populations decreased from day 3 to day 10 (CD45, CD11b, CD68, CCR7, CD163, CD206, CD3, CD4).

We confirmed the earlier finding ${ }^{20 ; 66}$, indicating that administration of NSAIDs during the inflammatory phase has a negative effect on tendon healing. However, treatment with parecoxib during the early remodeling phase has been shown to have a slight positive effect ${ }^{20}$. During early tendon healing, the newly formed tissue is composed of a great percentage of leukocytes (CD45) ${ }^{67}$. The leukocyte subpopulation composition was greatly influenced by mechanical loading in study I. These findings made us speculate that NSAIDs influencing tendon healing mechanically might also alter the leukocyte subpopulation. Unexpectedly, we found that the effects of NSAIDs on tendon healing is not mediated through changing the leukocyte subpopulations.

$\mathrm{EP} 2$ and EP4 receptor-selective agonists stimulate the EP2 and EP4 receptors to increase the activity, proliferation, and differentiation of mesenchymal stem cells into osteoblasts ${ }^{68-70}$. NSAIDs inhibit the COX enzymes and thereby the 
production of PGE2 and have a negative effect on bone healing ${ }^{71 ; 72}$ by reducing the proliferation and differentiation of mesenchymal stem cells into osteoblasts that are cells responsible for new bone formation. NSAIDs might have a similar inhibitory effect on proliferation and differentiation of mesenchymal stem cells to tendon cells through EP2 and Ep4 receptor-agonist mechanisms. It has been shown that NSAIDs have an inhibitory effect on proliferation and migration of tendon cells in culture $73-75$. In conclusion, the effects of NSAIDs on mechanical properties of tendon seem to be independent of changing the leukocyte composition including the different subpopulation of macrophages and $\mathrm{T}$ cells.

\section{Study III}

In this study, we investigated if suppression of inflammation during the early remodeling phase, by systemic administration of dexamethasone, could improve tendon healing.

We first evaluated the early dexamethasone treatment during the inflammatory phase in our Achilles tendon healing model, expecting a deleterious effect of the treatment as the literature suggests. Mechanical evaluation at day 7 showed that early dexamethasone treatment reduced peak force, stiffness and crosssectional area. In the second part of the experiment, dexamethasone was administered after the early inflammatory phase. Since inflammation might disturb remodeling, we hypothesized that systemic treatment with corticosteroid has beneficial effects on tendon healing. Mechanical evaluation at day 12 showed an increase in peak force and stiffness, and decreased crosssectional area following dexamethasone treatment compared to controls. Material properties (stress and elastic modulus) were also improved. Histology evaluation showed that dexamethasone promoted tissue organization (Figure 6). Furthermore, flow cytometry evaluation revealed a reduction in CD8a cytotoxic $\mathrm{T}$ cells in the dexamethasone group both at 7 and 12 days. Improved healing and tissue organization following late dexamethasone treatment could be associated to the decrease in the CD8a cytotoxic T cells. There are similar 
findings in the bone healing field where depletion of CD8 $\mathrm{T}$ cells in mice improved fracture healing and reconstitution of CD8 T cells impaired it 76 .

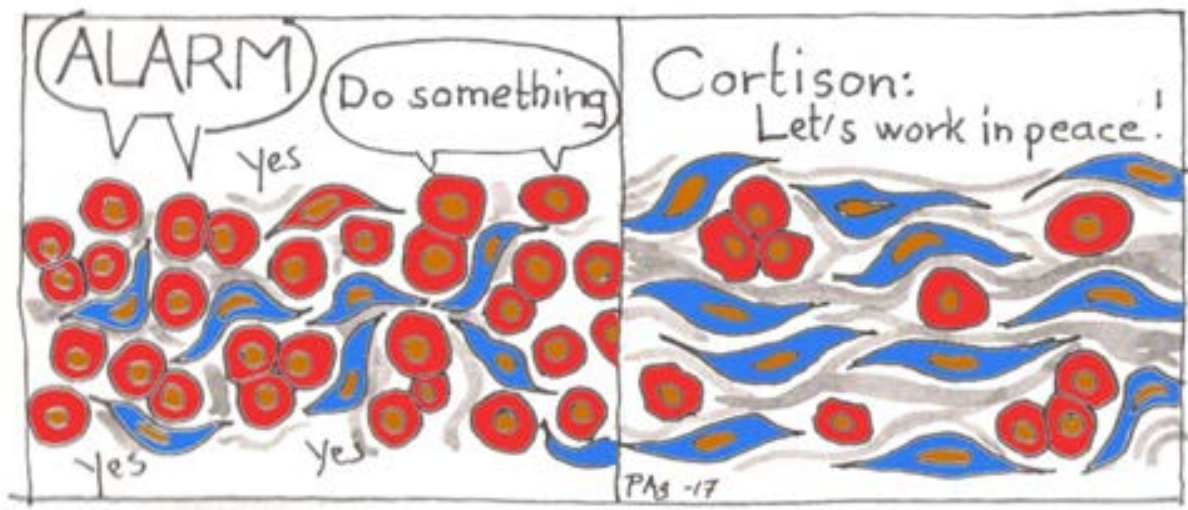

Figure 6. Corticosteroids reduce inflammation and organize the tissue during early remodeling.

\section{Study IV}

Mechanical loading stimulates early tendon healing, and COX inhibitors impair it. We investigated if impairment of tendon healing by a COX-2 inhibitor is mediated via inhibiting the stimulatory effect of mechanotransduction or microdamage.

\section{Loading experiment:}

With increased loading, the peak force at failure also increased. Parecoxib (COX-2 inhibitor) reduced peak force compared to the saline injected group. There was a statistically significant interaction between loading and parecoxib for peak force, indicating that the effects of parecoxib increased with increased loading. However, analysis of log-transformed values showed no significant interaction between parecoxib and loading. This means that parecoxib reduced the peak force at failure by a fixed percentage regardless of the degree of loading. 
Microdamage Experiment:

Microdamage induced by needling increased peak force at failure compared to controls (Botox with no needling). This increase in peak force by needling was completely abrogated by parecoxib.

COX-2 inhibited the stimulatory effect of loading and needling. Ln-transformed data in the loading experiment showed no significant interaction between COX2 inhibition and loading. Even though COX-2 inhibition impaired the positive effect that mechanical loading had on tendon healing, based on the lntransformed data, it seems that the inhibitory effect of parecoxib is not orchestrated via interfering with mechanotransduction during loading since parecoxib reduced the peak force with a fixed percentage in all loading groups regardless of the degree of loading. Next, we hypothesized that the inhibitory effect of parecoxib might be related to the stimulatory effect of microdamage induced by mechanical loading rather than mechanotransduction.

In order to study only the effect of microdamage, but not mechanical loading, we moderately unloaded the tendon by Botox injections and induced microdamage by needling in the second experiment. The strongest inhibitory effect of COX-2 inhibition was seen when microdamage was applied to stimulate Achilles tendon healing, where parecoxib completely eliminated the stimulatory effect. This suggests that COX-2 inhibition attenuates the positive effect of mechanical loading during tendon healing mainly by reducing the response to microdamage.

When comparing complete unloading (Botox injection together with tail suspension) to moderate unloading model (Botox injection) we observed an increase in peak force in healing tendon in the moderate unloaded group without increase in the cross-sectional area. By increasing, the loading levels further to the full loading (free cage activity), peak force and cross-sectional area increased compared to that of moderate unloading and complete unloading. Microdamage also increased cross-sectional area. This suggests that the 
microdamage effects occurred mostly in the fully loaded group. Furthermore, parecoxib reduced the cross-sectional area that was increased by microdamage. In the loading experiment parecoxib lowered the cross-sectional area mainly in the fully loaded group. This again shows that effect of parecoxib is associated to decreased response to microdamage.

Parecoxib did not affect the elastic modulus and stress, which represent tissue quality and is a result of mechanotransduction. This further shows that COX-2 inhibition does not interfere with mechanotransduction.

These results suggest that $\mathrm{COX}-2$ and PGE2 production in response to mechanical loading during early tendon healing is essential and its inhibition has detrimental effects on the healing of tendon mainly through inhibiting the stimulatory effect of microdamage. 
Microdamage induced by needling in the healing tissue stimulates healing in a similar way to mechanical loading and the gene expression activated by mechanical loading and microdamage seems to be similar ${ }^{16}$. Mechanical loading creates microdamage in the tissue as micro-bleeding. We have detected microdamage in the form of blood leakage in the healing tissue 3 and 5 days after tendon transection in the fully loaded groups in our rat tendon healing model (unpublished data; Hammerman, Blomgran et al.). Microdamage might stimulate the tendon healing tissue by increasing the infiltration of immune cells, as the gene expression analysis at day 3 and day 5 has shown where mechanical loading upregulated inflammation related genes 3 ; 4. Study IV suggested that the microdamage component of loading occurred mainly in the fully loaded group. This result is in accordance with our finding in study I, where full loading keeps the inflammation ongoing: at 10 days after surgery, there was a prolonged presence of M1 macrophages and delay to switch to M2 macrophages and regulatory $\mathrm{T}$ cells, which are responsible for down regulating the inflammation.

Full loading increases the cross-sectional area and this seems to be related to microdamage that is induced by mechanical loading, which leads to ongoing inflammation in the healing tissue and an increase in the mass of healing tissue. However, in the moderately unloaded group, there was minimal microdamage and we have seen that increasing the loading from complete unloading to minimal loading with Botox, mainly tissue quality increases without an increase in the cross-sectional area. In addition, the fact that inflammation in the Botoxtreated animals resolves between 5 and 10 days again suggests that there is little microdamage in the healing tendon tissue of Botox-treated animals. This explains why we do not see an increase in callus size by Botox compared to complete unloading. Resolution of inflammation in moderately unloaded animals between 5 and 10 days could be of clinical interest. As findings in study 
III suggests that prolonged inflammation disturbs the remodeling phase and its down regulation is beneficial. Therefore, early controlled weight bearing in patients after tendon rupture, which corresponds to our moderate unloaded model in rats, not only stimulates tendon healing but also can resolve the inflammation, which might contribute to further improvement in tissue quality without the interference of inflammation with remodeling phase.

During early tendon healing, NSAIDs do not influence the quality of the tissue represented by stress and elastic modulus and thereby mechanotransduction. Our finding in study IV showed that negative effects of NSAIDs during early tendon healing are related to abrogation of the stimulatory effects of microdamage. However, it has been shown that administration of NSAIDs after the early inflammatory phase and during the early remodeling phase increases the maximum stress ${ }^{20}$. Corticosteroid treatment during the early remodeling phase also improves peak stress and elastic modulus. Both NSAIDs and corticosteroids improve tissue quality when given during the early remodeling phase, and tissue quality partly reflects the organization of tissue that is a result of mechanotransduction. Cells sense and respond to mechanical stimuli during the remodeling phase via mechanotransduction and produce collagen in the direction of the force and organize the tissue. Hence, any factor interfering with mechanotransduction, like inflammation, can disrupt the remodeling phase and its down regulation should be beneficial.

Early corticosteroid treatment makes the tendon regenerate weaker. We noticed an increase in $\mathrm{CD} 45^{+}$cells with early dexamethasone treatment. This suggests that proliferation of other cells, like mesenchymal cells, might have been reduced. It has been shown that corticosteroids inhibits the differentiation of tendon stem cells into tenocytes in vitro 77 . Macrophages as a part of the innate immune response and $\mathrm{T}$ cells as a part of the adaptive immune response produce IL- 6 and TGF- $\beta$ that regulate bone marrow mesenchymal stem cells ${ }^{78-}$ 80. Corticosteroids reduce TGF- $\beta$ expression ${ }^{81}$ by macrophages and $\mathrm{T}$ cells and can thereby impair healing. TGF- $\beta$ regulates proliferation, differentiation and extracellular matrix production ${ }^{82}$. Therefore, TGF- $\beta$ seems to have an 
important role during early tendon healing and its inhibition by corticosteroids might be a cause for impaired healing.

IL-6 expression has been reported to be highly sensitive to mechanical loading at day 3 after injury and had the highest fold change among all the genes that were regulated by mechanical loading ${ }^{3}$. IL-6 deficiency has been shown to result in thinner tendons and to impair healing, and IL-6 injection stimulates collagen production ${ }^{83-85}$. All these findings highlight the importance of TGF- $\beta$ and IL-6 production by immune cells for normal tendon healing, function and structure. Our results point out the importance of further studying the secretory function of macrophages and $\mathrm{T}$ cells that regulate normal tendon healing and how that is influenced by corticosteroid treatment. 
I. Mechanical loading prolonged the presence of M1 macrophages and delayed the switch to M2 macrophages and regulatory T cells.

II. Negative effects of NSAIDs on early tendon healing might be exerted via mechanisms not directly related to frequency of inflammatory cells.

III. Corticosteroid treatment improves tendon healing when started after the early inflammatory phase.

IV. COX-2 inhibition by NSAIDs impairs the positive and stimulatory effects of mechanical loading during early tendon healing, mainly by reducing the response to microdamage.

Factors that tamper with inflammation, like mechanical loading and corticosteroids, also tamper with Achilles tendon healing.

Our moderate unloading model not only stimulates tendon healing but also helps to resolve inflammation, which is important for an optimal healing and for rebuilding tissue with a better quality. Unresolved inflammation interferes with the remodeling phase of healing. Therefore, early controlled weight bearing in humans after tendon rupture, which corresponds to our moderate unloading model, might be beneficial with respect to resolving inflammation and improving tissue quality in patients.

Systemic corticosteroid treatment after the early inflammatory phase in humans might accelerate the healing process. 


\section{ACKNOWLEDGEMENT}

I would like to express my appreciation to all who have contributed and supported me and made this thesis possible.

Per Aspenberg, my supervisor, for your admirable devotion to your work, sharing your extensive knowledge, having so many ideas, great vision, and giving me hope every time we got rejected from journals.

Jan Ernerudh, my co-supervisor, your calmness makes me calm. After 4 rejections on my first paper your suggestion for the journal Scientific Reports was light in the darkness, I became "stamkund".

My colleagues, Malin Hammerman, from the beginning to the end, thanks for all our good moments in the office, our funny experiences in the animal facility, all nice travels we did together, and being a good partner for our team tendon, next book will be yours. Olof Sandberg my dear friend, for our joyful times in the office, playing our remote control car, all those cold Coca Colas you shared with me and for being a great listener, I missed you every day since you left. Pernilla Eliasson, for all our discussions about everything, I'm very happy you will keep the candle of tendon research burning. Veronika Koeppen, for good friendship and great company, I am looking forward to more Oktoberfest's in Munich with you. Franciele Dietrich, we should plan a trip to Amazonia before the Indians start to suit up. Team bone: Magnus Bernhardsson and Love Tätting for presenting new findings with bone healing that helped me to learn beyond my inflammation and tendon world. Anna-Carin, Anna, Bibbi, Brandon, Fredrik, Jahan, Jörg, Sandra for being on board on our research boat.

Mehdi Amirhosseini, for always being there to talk to about everything, from the beginning of our Master studies all the way to the end. 
Anna Fahlgren, for our nice trips to the US and discussions about science and life.

Hanifeh Khayyeri, it was so nice to get to know you, I wish you had stayed longer in Linköping.

Simin Mohseni, for your kindness, generosity, and being so caring.

The members of Forum Scientium and specially Stefan Klintström for all the fun times at our study visits and conferences, I wish I could stay with Forum forever.

Marcel Bassirian, for all your positive energy and reminding me how short this life is and to live it to the fullest, there is a lot left to learn from you.

My parents, for your unconditional love and support and always believing in me. Without you, I would not be where I am today.

My grandmother, for raising me to be strong and independent.

My grandfather, Oxford graduate orthopedic surgeon, who unfortunately passed away too early in my life, but has taught me life is much more than titles and education. I will keep travelling the world, meeting new people and embrace what the world has to offer.

Robert Blomgran, my love, my everything. Tack för att du finns. Such a beautiful journey our life has been together and thanks for accompanying me all over the world, we have 51 countries left to travel to $\odot$. . For all the nights, I had to work late and for all the weekends I have spent in the animal facility, during which you also stayed longer at your department so we could go home together. For getting me started with the method developed in this thesis. Half of this thesis really belongs to you. 


\section{REFERENCES}

1. Wang JH. 2006. Mechanobiology of tendon. J Biomech 39:1563-1582.

2. Eliasson P, Andersson T, Aspenberg P. 2009. Rat Achilles tendon healing: mechanical loading and gene expression. J Appl Physiol (1985) 107:399-407.

3. Hammerman M, Blomgran P, Dansac A, et al. 2017. Different gene response to mechanical loading during early and late phases of rat Achilles tendon healing. J Appl Physiol (1985):jap 0032302017.

4. Eliasson P, Andersson T, Aspenberg P. 2012. Influence of a single loading episode on gene expression in healing rat Achilles tendons. J Appl Physiol (1985) 112:279-288.

5. Park JE, Barbul A. 2004. Understanding the role of immune regulation in wound healing. Am J Surg 187:11S-16S.

6. de la Durantaye M, Piette AB, van Rooijen N, et al. 2014. Macrophage depletion reduces cell proliferation and extracellular matrix accumulation but increases the ultimate tensile strength of injured Achilles tendons. J Orthop Res 32:279-285.

7. Peterson JM, Barbul A, Breslin RJ, et al. 1987. Significance of Tlymphocytes in wound healing. Surgery 102:300-305.

8. Barbul A, Breslin RJ, Woodyard JP, et al. 1989. The effect of in vivo T helper and T suppressor lymphocyte depletion on wound healing. Ann Surg 209:479-483.

9. Efron JE, Frankel HL, Lazarou SA, et al. 1990. Wound healing and Tlymphocytes. J Surg Res 48:460-463.

10. Sharma P, Maffulli N. 2006. Biology of tendon injury: healing, modeling and remodeling. J Musculoskelet Neuronal Interact 6:181-190.

11. Andersson T, Eliasson P, Hammerman M, et al. 2012. Low-level mechanical stimulation is sufficient to improve tendon healing in rats. $\mathrm{J}$ Appl Physiol (1985) 113:1398-1402.

12. Eliasson P, Andersson T, Aspenberg P. 2012. Achilles tendon healing in rats is improved by intermittent mechanical loading during the inflammatory phase. J Orthop Res 30:274-279. 
13. Andersson T, Eliasson P, Aspenberg P. 2009. Tissue memory in healing tendons: short loading episodes stimulate healing. J Appl Physiol (1985) 107:417-421.

14. Palmes D, Spiegel HU, Schneider TO, et al. 2002. Achilles tendon healing: long-term biomechanical effects of postoperative mobilization and immobilization in a new mouse model. J Orthop Res 20:939-946.

15. Eliasson P, Andersson T, Hammerman M, et al. 2013. Primary gene response to mechanical loading in healing rat Achilles tendons. J Appl Physiol (1985) 114:1519-1526.

16. Hammerman M, Aspenberg P, Eliasson P. 2014. Microtrauma stimulates rat Achilles tendon healing via an early gene expression pattern similar to mechanical loading. J Appl Physiol (1985) 116:54-60.

17. Yuan C, Sidhu RS, Kuklev DV, et al. 2009. Cyclooxygenase Allosterism, Fatty Acid-mediated Cross-talk between Monomers of Cyclooxygenase Homodimers. J Biol Chem 284:10046-10055.

18. Vane JR. 1971. Inhibition of prostaglandin synthesis as a mechanism of action for aspirin-like drugs. Nat New Biol 231:232-235.

19. Chen MR, Dragoo JL. 2013. The effect of nonsteroidal anti-inflammatory drugs on tissue healing. Knee Surg Sports Traumatol Arthrosc 21:540549 .

20. Virchenko O, Skoglund B, Aspenberg P. 2004. Parecoxib impairs early tendon repair but improves later remodeling. Am J Sports Med 32:17431747 .

21. Connizzo BK, Yannascoli SM, Tucker JJ, et al. 2014. The detrimental effects of systemic Ibuprofen delivery on tendon healing are timedependent. Clin Orthop Relat Res 472:2433-2439.

22. Dimmen S, Engebretsen L, Nordsletten L, et al. 2009. Negative effects of parecoxib and indomethacin on tendon healing: an experimental study in rats. Knee Surg Sports Traumatol Arthrosc 17:835-839.

23. Su B, O'Connor JP. 2013. NSAID therapy effects on healing of bone, tendon, and the enthesis. J Appl Physiol (1985) 115:892-899.

24. Manning CN, Havlioglu N, Knutsen E, et al. 2014. The early inflammatory response after flexor tendon healing: a gene expression and histological analysis. J Orthop Res 32:645-652. 
25. Yang G, Im HJ, Wang JH. 2005. Repetitive mechanical stretching modulates IL-1beta induced COX-2, MMP-1 expression, and PGE2 production in human patellar tendon fibroblasts. Gene 363:166-172.

26. Zhang J, Wang JH. 2010. Production of PGE(2) increases in tendons subjected to repetitive mechanical loading and induces differentiation of tendon stem cells into non-tenocytes. J Orthop Res 28:198-203.

27. Forslund C, Bylander B, Aspenberg P. 2003. Indomethacin and celecoxib improve tendon healing in rats. Acta Orthop Scand 74:465-469.

28. Thomas J, Taylor D, Crowell R, et al. 1991. The effect of indomethacin on Achilles tendon healing in rabbits. Clin Orthop Relat Res:308-311.

29. Glyn J. 1998. The discovery and early use of cortisone. J R Soc Med 91:513-517.

30. Hench PS, Kendall EC, et al. 1949. The effect of a hormone of the adrenal cortex (17-hydroxy-11-dehydrocorticosterone; compound E) and of pituitary adrenocorticotropic hormone on rheumatoid arthritis. Proc Staff Meet Mayo Clin 24:181-197.

31. Speed CA. 2001. Fortnightly review: Corticosteroid injections in tendon lesions. BMJ 323:382-386.

32. Cain DW, Cidlowski JA. 2017. Immune regulation by glucocorticoids. Nat Rev Immunol 17:233-247.

33. Kim SW, Rhee HJ, Ko J, et al. 2001. Inhibition of cytosolic phospholipase A2 by annexin I. Specific interaction model and mapping of the interaction site. J Biol Chem 276:15712-15719.

34. Perretti M, Ahluwalia A. 2000. The microcirculation and inflammation: site of action for glucocorticoids. Microcirculation 7:147-161.

35. Ehrchen J, Steinmuller L, Barczyk K, et al. 2007. Glucocorticoids induce differentiation of a specifically activated, anti-inflammatory subtype of human monocytes. Blood 109:1265-1274.

36. Giles KM, Ross K, Rossi AG, et al. 2001. Glucocorticoid augmentation of macrophage capacity for phagocytosis of apoptotic cells is associated with reduced p13oCas expression, loss of paxillin/pyk2 phosphorylation, and high levels of active Rac. J Immunol 167:976-986.

37. Martinez FO, Sica A, Mantovani A, et al. 2008. Macrophage activation and polarization. Front Biosci 13:453-461. 
38. Balasubramaniam P, Prathap K. 1972. The effect of injection of hydrocortisone into rabbit calcaneal tendons. J Bone Joint Surg $\mathrm{Br}$ 54:729-734.

39. Kapetanos G. 1982. The effect of the local corticosteroids on the healing and biomechanical properties of the partially injured tendon. Clin Orthop Relat Res:170-179.

40. Tatari H, Kosay C, Baran O, et al. 2001. Deleterious effects of local corticosteroid injections on the Achilles tendon of rats. Arch Orthop Trauma Surg 121:333-337.

41. Mikolyzk DK, Wei AS, Tonino P, et al. 2009. Effect of corticosteroids on the biomechanical strength of rat rotator cuff tendon. J Bone Joint Surg Am 91:1172-1180.

42. Nakamura H, Gotoh M, Kanazawa T, et al. 2015. Effects of corticosteroids and hyaluronic acid on torn rotator cuff tendons in vitro and in rats. $\mathrm{J}$ Orthop Res 33:1523-1530.

43. Hugate R, Pennypacker J, Saunders M, et al. 2004. The effects of intratendinous and retrocalcaneal intrabursal injections of corticosteroid on the biomechanical properties of rabbit Achilles tendons. J Bone Joint Surg Am 86-A:794-801.

44. Unverferth LJ, Olix ML. 1973. The effect of local steroid injections on tendon. J Sports Med 1:31-37.

45. Kennedy JC, Willis RB. 1976. The effects of local steroid injections on tendons: a biomechanical and microscopic correlative study. Am J Sports Med 4:11-21.

46. Franz MG, Steed DL, Robson MC. 2007. Optimizing healing of the acute wound by minimizing complications. Curr Probl Surg 44:691-763.

47. Guo S, Dipietro LA. 2010. Factors affecting wound healing. J Dent Res 89:219-229.

48. Wong MW, Lui WT, Fu SC, et al. 2009. The effect of glucocorticoids on tendon cell viability in human tendon explants. Acta Orthop 80:363-367.

49. Tsai WC, Tang FT, Wong MK, et al. 2003. Inhibition of tendon cell migration by dexamethasone is correlated with reduced alpha-smooth muscle actin gene expression: a potential mechanism of delayed tendon healing. J Orthop Res 21:265-271. 
50. Dean BJ, Lostis E, Oakley T, et al. 2014. The risks and benefits of glucocorticoid treatment for tendinopathy: a systematic review of the effects of local glucocorticoid on tendon. Semin Arthritis Rheum 43:570576.

51. Mackie JW, Goldin B, Foss ML, et al. 1974. Mechanical properties of rabbit tendons after repeated anti-inflammatory steroid injections. Med Sci Sports 6:198-202.

52. Shapiro PS, Rohde RS, Froimson MI, et al. 2007. The effect of local corticosteroid or ketorolac exposure on histologic and biomechanical properties of rabbit tendon and cartilage. Hand (N Y) 2:165-172.

53. Oxlund H. 1980. The influence of a local injection of cortisol on the mechanical properties of tendons and ligaments and the indirect effect on skin. Acta Orthop Scand 51:231-238.

54. Phelps D, Sonstegard DA, Matthews LS. 1974. Corticosteroid injection effects on the biomechanical properties of rabbit patellar tendons. Clin Orthop Relat Res:345-348.

55. Matthews LS, Sonstegard DA, Phelps DB. 1974. A biomechanical study of rabbit patellar tendon: effects of steroid injection. J Sports Med 2:349357.

56. Plotkin MB, Foss ML, Goldin B, et al. 1976. Dose-response effects of antiinflammatory steroid injections on mechanical properties of rat tail tendons. Med Sci Sports 8:230-234.

57. Martins CA, Bertuzzi RT, Tisot RA, et al. 2012. Dextrose prolotherapy and corticosteroid injection into rat Achilles tendon. Knee Surg Sports Traumatol Arthrosc 20:1895-1900.

58. Martinez FO, Gordon S. 2014. The M1 and M2 paradigm of macrophage activation: time for reassessment. F100oPrime Rep 6:13.

59. Shearer JD, Richards JR, Mills CD, et al. 1997. Differential regulation of macrophage arginine metabolism: a proposed role in wound healing. Am J Physiol 272:E181-190.

60. Mantovani A, Sica A, Sozzani S, et al. 2004. The chemokine system in diverse forms of macrophage activation and polarization. Trends Immunol 25:677-686.

61. Arango Duque G, Descoteaux A. 2014. Macrophage cytokines: involvement in immunity and infectious diseases. Front Immunol 5:491. 
62. Zhu J, Yamane H, Paul WE. 2010. Differentiation of effector CD4 T cell populations (*). Annu Rev Immunol 28:445-489.

63. Abbas AK, Lichtman AH, Pillai S. 2012. Cellular and molecular immunology, 7th ed. Philadelphia: Elsevier/Saunders; x, 545 p. p.

64. Workman CJ, Szymczak-Workman AL, Collison LW, et al. 2009. The development and function of regulatory T cells. Cell Mol Life Sci 66:26032622.

65. Beura LK, Hamilton SE, Bi K, et al. 2016. Normalizing the environment recapitulates adult human immune traits in laboratory mice. Nature 532:512-516.

66. Hammerman M, Blomgran P, Ramstedt S, et al. 2015. COX-2 inhibition impairs mechanical stimulation of early tendon healing in rats by reducing the response to microdamage. J Appl Physiol (1985) 119:534540 .

67. Blomgran P, Blomgran R, Ernerudh J, et al. 2016. A possible link between loading, inflammation and healing: Immune cell populations during tendon healing in the rat. Sci Rep 6:29824.

68. Paralkar VM, Borovecki F, Ke HZ, et al. 2003. An EP2 receptor-selective prostaglandin E2 agonist induces bone healing. Proc Natl Acad Sci U S A 100:6736-6740.

69. Li M, Ke HZ, Qi H, et al. 2003. A novel, non-prostanoid EP2 receptorselective prostaglandin E2 agonist stimulates local bone formation and enhances fracture healing. J Bone Miner Res 18:2033-2042.

70. Ke HZ, Crawford DT, Qi H, et al. 2006. A nonprostanoid EP4 receptor selective prostaglandin E2 agonist restores bone mass and strength in aged, ovariectomized rats. J Bone Miner Res 21:565-575.

71. Burd TA, Hughes MS, Anglen JO. 2003. Heterotopic ossification prophylaxis with indomethacin increases the risk of long-bone nonunion. J Bone Joint Surg Br 85:700-705.

72. Sandberg O, Aspenberg P. 2015. Different effects of indomethacin on healing of shaft and metaphyseal fractures. Acta Orthop 86:243-247.

73. Tsai WC, Hsu CC, Chen CP, et al. 2006. Ibuprofen inhibition of tendon cell migration and down-regulation of paxillin expression. J Orthop Res 24:551-558. 
74. Tsai WC, Hsu CC, Chou SW, et al. 2007. Effects of celecoxib on migration, proliferation and collagen expression of tendon cells. Connect Tissue Res 48:46-51.

75. Tsai WC, Tang FT, Hsu CC, et al. 2004. Ibuprofen inhibition of tendon cell proliferation and upregulation of the cyclin kinase inhibitor p21CIP1. J Orthop Res 22:586-591.

76. Reinke S, Geissler S, Taylor WR, et al. 2013. Terminally differentiated CD8(+) T cells negatively affect bone regeneration in humans. Sci Transl Med 5:177ra136.

77. Chen W, Tang H, Zhou M, et al. 2015. Dexamethasone inhibits the differentiation of rat tendon stem cells into tenocytes by targeting the scleraxis gene. J Steroid Biochem Mol Biol 152:16-24.

78. Rodriguez Mdel C, Bernad A, Aracil M. 2004. Interleukin-6 deficiency affects bone marrow stromal precursors, resulting in defective hematopoietic support. Blood 103:3349-3354.

79. Schaper F, Rose-John S. 2015. Interleukin-6: Biology, signaling and strategies of blockade. Cytokine Growth Factor Rev 26:475-487.

80. Nacu N, Luzina IG, Highsmith K, et al. 2008. Macrophages produce TGFbeta-induced (beta-ig-h3) following ingestion of apoptotic cells and regulate MMP14 levels and collagen turnover in fibroblasts. J Immunol 180:5036-5044.

81. Wicke C, Halliday B, Allen D, et al. 2000. Effects of steroids and retinoids on wound healing. Arch Surg 135:1265-1270.

82. Killian ML, Cavinatto L, Galatz LM, et al. 2012. The role of mechanobiology in tendon healing. J Shoulder Elbow Surg 21:228-237.

83. Lin TW, Cardenas L, Soslowsky LJ. 2005. Tendon properties in interleukin-4 and interleukin-6 knockout mice. J Biomech 38:99-105.

84. Andersen MB, Pingel J, Kjaer M, et al. 2011. Interleukin-6: a growth factor stimulating collagen synthesis in human tendon. J Appl Physiol (1985) 110:1549-1554.

85. Lin TW, Cardenas L, Glaser DL, et al. 2006. Tendon healing in interleukin-4 and interleukin-6 knockout mice. J Biomech 39:61-69. 


\section{Papers}

The papers associated with this thesis have been removed for copyright reasons. For more details about these see:

http:// urn.kb.se/ resolve?urn=urn:nbn:se:liu:diva-142349 